\title{
OPERATIONALIZING AND REGULATING RELIGIOUS FREEDOM: APOSTASY AND ADMINISTRATIVE "REASONABLENESS" IN MALAYSIA AND BEYOND
}

\author{
Matthew J. Nelson ${ }^{1}$ and Dian A. H. Shah ${ }^{2}$
}

INTRODUCTION

The operationalization of human rights is often framed by complex procedural requirements tied to forms of state recognition. This, however, becomes especially complicated where questions of identity or status are implicated. An obvious example is the right to religious freedom, which encompasses the right to choose and change one's religion identity. In this respect, the administrative link between one's religious identity and the state's recognition of that identity is particularly important where a change in religion affects one's status vis-à-vis religious laws or institutions (e.g. privileged access to religious education or benefits and whether one is subject to the jurisdiction of religious courts or authorities). The balance between a fundamental right to religious self-identification and the administrative procedures surrounding state recognition is a delicate one. When do administrative procedures amount to an excessive burden and, thus, a violation of one's right to religious self-identification? When do state-based procedures amount to an infringement on fundamental rights?

Within this context, cases of religious conversion are multi-dimensional. On the one hand, conversion is tied to religious profession as a fundamental right. On the other hand, such cases often involve forms of state recognition with all of the administrative requirements this entails: notarized declarations, detailed paperwork, bureaucratic discretion, and so on. These hurdles move beyond the question of religious profession to include both the manifestation and the recognition of one's religious identity within the public realm. Human rights advocates typically describe the right to profess a specific religion or belief (religious self-identification) as absolute. ${ }^{3}$ Matters of manifestation, however, are subject to constraints established by law. This article concerns the realm of administrative constraint — constraints tied to the very procedures that allow states to recognize one's religious identity.

A brief example will help to illustrate this link between fundamental rights and administrative procedures. In 2009, the U.K. Supreme Court decided a case involving a boy who applied for admission to a prominent school in London known as the Jewish Free

${ }^{1}$ Matthew Nelson (PhD, Columbia) is a Reader in Politics at the School of Oriental and African Studies (SOAS), University of London.

${ }^{2}$ Dian A. H. Shah (SJD, Duke) is a Research Fellow at the Centre for Asian Legal Studies in the Faculty of Law at the National University of Singapore and a Senior Lecturer in Law at the University of Malaya.

${ }^{3}$ Nurjaanah Abdullah, Legislating Faith in Malaysia, Singapore J. Legal Stud. 264, 274 (2007). 
School. ${ }^{4}$ The boy had a Jewish father and a mother who converted to Judaism under the supervision of a Masorti (Conservative) rabbi. However, the school had a preferential admissions policy that emphasized Orthodox ideas about descent from an Orthodox mother (or her conversion by an Orthodox rabbi) rather than the child's religious belief or practice. Because the school's policy focused on maternal descent rather than religious belief or practice, the Court ruled that the school's admissions policy violated British laws against ethnic or racial discrimination. ${ }^{5}$ In effect, the school rejected a "self-identification" standard and the Court rejected a "descent-based" standard for determining Jewishness; the Court ordered the school to develop a new procedure for judging who was (and who was not) a Jew for the purpose of admission. In other words, the state required a new set of administrative procedures to facilitate a legally binding approach to the recognition of religious identity.

Administrative procedures are ubiquitous in cases of religious recognition. But what counts as a "reasonable" procedural burden? We argue that administrative and procedural burdens are an inevitable feature of state recognition. However, we also stress that, insofar as this is the case, historically and politically contingent questions of administrative "reasonableness" are baked into the constitutional operationalization of basic rights. Administrative procedures connect matters of religious self-identification to patterns of state recognition, but in postcolonial countries with some attachment to British common-law traditions like Malaysia, efforts to determine the "reasonableness" of those procedures - and, therein, the practical operationalization of religious freedom - continue to reflect the political elasticity associated with Britain's "political" constitution. ${ }^{6}$ The operationalization of fundamental rights pertaining to religious freedom, we argue, varies across time and space owing to the presence of politically inflected ideas about what counts as a "reasonable" administrative procedure.

Since the landmark decision in Smith and Grady v. the United Kingdom (1999), which followed shortly after the promulgation of Britain's new Human Rights Act (1998), British courts have shifted their assessment of administrative procedures that might restrict the enjoyment of an individual right. They have slowly moved away from the rather deferential Wednesbury "unreasonableness" test (according to which an administrative act is respected unless it becomes so capricious, perverse, or absurd that "no reasonable authority could have ... come to it" ${ }^{7}$ ) in favour of a more rigorous "proportionality" test (within which policy makers and administrative actors must show that the limitations they impose are offset by a "proportional" enhancement of some legitimate public interest). ${ }^{8}$ Some argue that this shift

${ }^{4} R(E)$ v Governing Body of JFS \& Others, U.K.S.C. 15(2009).

${ }^{5} I d$., per Lord Clarke at paras. 131 and 148.

${ }^{6}$ See J.A.G. Griffith, The Political Constitution, Modern L. Rev. 42 (1979), 1; Adam Tomkins, The Role of the Courts in the Political Constitution, 60 (1) Univ. Toronto L. J. 1 (2010); Thomas Poole, The Reformation of English Administrative Law, 68 (1) CAMBridge L. J. 142 (2009).

${ }^{7}$ Associated Provincial Picture Houses Ltd. v Wednesbury Corporation 1 K.B. 223 (1948) at 234.

${ }^{8}$ For an account of this shift from Wednesbury reasonableness to proportionality, see G.L. Peiris, Wednesbury Unreasonableness: The Expanding Canvas, 46 (1) CAMBRIDGE L. J. 53 (1987). Also, turning to regarding fundamental rights, see Jeffrey Jowell and A. Lester, Beyond Wednesbury: Substantive Principles of Administrative Law, Public Law 368 (1987); Clive Lewis, The European Convention, Proportionality, and the 
has altered the traditional balance of power between the political (administrative) and judicial arms of British constitutionalism, privileging more centralized forms of judicial power and a relatively more static understanding of human rights - a source of gratification for some and lamentation for others. ${ }^{9}$ Yet, in respecting Britain's political constitution, the sovereignty of parliament, and the power of an elected government and its civil servants, both approaches continue to leave a great deal of room for politics and administrative discretion. The operationalization of basic rights is never free-standing; either way, it remains closely tied to a judicial assessment of executive (administrative) action.

In what follows we focus on one case of religious conversion and state-based religious recognition in Malaysia - the famous case of Lina Joy. ${ }^{10}$ In this case, historically and politically contingent notions of administrative "reasonableness" emerged as a crucial variable in the operationalization of religious liberty. In Britain, the administrative action associated with this case - a refusal to accept the self-identification of a Muslim-to-Christian convert without the corresponding completion of specific bureaucratic procedures (procedures that remained undefined, indeed, without any covering legislation whatsoever) - might have been judged in terms of "proportionality" because a fundamental right (religious freedom) was at stake. The government might have been required to stress a "public interest" in avoiding legislative or administrative support for conversions on the say-so of would-be converts owing to concerns, for instance, that (potentially reiterative) conversions might be motivated by a malafide effort to avoid this or that religious personal law. However, in Lina Joy, this concern for "proportionality" was not in play. Although Malaysia inherited both the common law tradition and numerous Westminster conventions, requiring a would-be convert named Lina Joy to complete a set of non-existent bureaucratic procedures was considered "reasonable" by a majority of Malaysia's Federal Court proceeding within the terms of Malaysia's federal constitution-ultimately, the supreme law of the land. Hence the question that motivates our examination of religious freedom: what do judicial notions of administrative "reasonableness" mean for the operationalization of basic rights and, as an inescapable empirical corollary, what does administrative "reasonableness" mean in the specific context of Malaysia? ${ }^{11}$

The argument we develop, regarding the role played by administrative procedures in the operationalization and regulation of human rights, is not confined to Malaysia. It extends to Jews in London, Christians in the U.S., and many others. In the recent case of Burwell vs. Hobby Lobby Stores, Inc., for instance, the U.S. Supreme Court allowed closely held companies and non-profit organizations articulating strong religious beliefs to claim an exemption from a government-supported national health insurance scheme covering

Broadcasting Ban, 50 (2) CAMBridge L. J. 211 (1991); Julian Rivers, Proportionality and Variable Intensity of Review, 65 (1) Cambridge L. J. 174 (2006); and Poole, supra note 4.

${ }^{9}$ See for e.g, Jowell and Lester, supra note 6; Tomkins, supra note 4; and Poole, supra note 4.

${ }^{10}$ Lina Joy v. Majlis Agama Islam Wilayah \& Anor, 4 Malay. L. J. 585 (2007).

${ }^{11}$ See Joshua Neoh, Islamic State and the Common Law in Malaysia: A Case Study of Lina Joy, GLoBAL JURIST 8 (2008). 
contraceptive services ("Obamacare"). ${ }^{12}$ After the Supreme Court decided to allow such exemptions, however, some religious groups objected to the administrative procedures involved in submitting their claims. A religious school known as Wheaton College, for example, argued that the government-issued forms they were required to complete (to claim an exemption) posed a substantial burden on their religious beliefs. In fact, moving beyond their right to profess a particular belief, the Court was asked to consider the "reasonableness" of the administrative procedures underpinning the state's recognition of that belief. Again the question was familiar: When do the administrative procedures associated with a state's recognition of religious identity amount to an "unreasonable" infringement and, thus, a violation of one's fundamental rights?

Increasingly, the U.S. Supreme Court has intervened, within individual states, to regulate the administrative procedures (e.g. the official forms) pertaining to intersecting federal and state-based rights like religious freedom, access to healthcare, and marriage. But, for a range of specific historical and political reasons we illuminate, Malaysia's Federal Court has shied away from any similar assertion of federal supremacy in cases involving Muslim apostasy. In fact, even as Malaysia has avoided more rigorous "proportionality" tests to judge the permissibility of administrative restrictions on a fundamental right to religious self-identification (in favour of more deferential "reasonableness" tests), the trajectory of Malaysia's courts in matters of Muslim apostasy has also rejected a federal doctrine stressing principles of federal supremacy (in favour of a focus on state-level subsidiarity). ${ }^{14}$ In short, the civil courts have typically deferred to state-level shari'ah courts and the administrative purview of state-level religious authorities in matters of Muslim apostasy (and Islamic law jurisdiction more generally). The question for the Federal Court has simply concerned the degree to which decisions taken by state-level officials have been "reasonable."

When Wheaton College claimed that its articulation of religious identity was frustrated by an undue administrative burden, its claim was tied to the content of particular forms (such that a change in content was expected to nullify the complaint). ${ }^{15}$ By contrast, in Lina Joy, the claim of unreasonableness was considerably more complicated. As noted above, the claim of unreasonableness was related to the state's insistence that, before it could formalize the self-identification of a Muslim-to-Christian convert named Lina Joy, Joy would have to complete a series of administrative procedures-procedures that did not yet exist. This burden struck many as unreasonable. And, yet, for richly contextualized reasons deeply rooted in Malaysia's constitutional, legal, and political history (specifically, judicial efforts to avoid preempting the constitutionally recognized bodies charged with defining and enforcing

\footnotetext{
${ }^{12}$ Burwell vs. Hobby Lobby Stores, Inc., 573 U.S. (2014).

${ }^{13}$ See Jeffrey A. Redding, Formal Marriage (2016) (unpublished manuscript, on file with author).

${ }^{14}$ This approach reflects the view of the U.S. Supreme Court in Erie Railroad v. Tompkins [1938],
} urging U.S. federal judges faced with overlapping federal and state-level jurisdictions to privilege state rather than federal laws to discourage forum-shopping.

${ }^{15}$ On Hobby Lobby, Wheaton College, and "[f]orms and paper ... far removed from the pomp and circumstance usually accompanying the high judicial art of pronouncing on rights", see Redding, supra note 11 at 3. "Paper forms", Redding notes, are "a new and hotly contested frontier mediating the relationship between religion and state." Redding, supra note 11 at 1 . 
relevant statutes and procedures), this burden was judged to be "reasonable". ${ }^{16}$

In what follows, we highlight the role that administrative procedures play in the operationalization of religious freedom. We do so by illuminating the persistent role that historically and politically contingent notions of "reasonableness" play in the judicial assessment of administrative procedures - specifically, the procedures that underpin official recognition of religious identity within Malaysia's (federated) states.

To locate Lina Joy in the literature on human rights and administrative "reasonable-ness," this article offers a close reading of the case in three parts. Part I describes the legal, political, and administrative landscape of Malaysia as this relates to issues of religious conversion away from Islam, drawing special attention to Malaysia's federal structure and its dual court system involving (a) a hierarchy of civil courts (including the Malaysian Federal Court) as well as (b) a hierarchy of state-level shari'ah courts overseen by state-level sultans who function as the constitutional Heads of Islam in their respective states. Beyond this dual court system, some attention is also paid to the constitutional limits faced by Malaysia's state-level shari'ah courts (in terms of their punitive jurisdiction) and, since 1988, the limits faced by Malaysia's civil courts - including the Federal Court-vis-à-vis their review of state-level judgments pertaining to shari'ah.

Part I also examines the role of state-level statutory enactments pertaining to Islamic law in matters of Muslim apostasy, along with the role of Malaysia's Department of Islamic Development, or JAKIM, now located in the Prime Minister's Office. With political support from JAKIM, several Malaysian state legislatures have introduced broadly similar administrative procedures pertaining to Muslim personal law, including Muslim laws concerning marriage, divorce, and conversion to Islam. This push in the direction of national legislative standards, however, has not affected conversions away from Islam. In fact, different Malaysian states continue to address this issue in different ways, with some-including the Federal Territories in which the case of Lina Joy emerged - failing to address it at all. As a constitutional, administrative, and political matter, this is the statutory lacuna that mattered (vis-à-vis questions of "reasonableness") in the case of Lina Joy.

Part II provides a detailed reading of Lina Joy, highlighting the ways in which Joy's lawyers and the Federal Court opted to set aside explicit fundamental rights claims in favour of a specific focus on the administrative procedures whereby Joy's religious identity was to be formally recognized (or not). Particular attention is paid to the statutory lacuna mentioned above and, within this, the view that expecting Joy to complete a set of (as-yet-non-existent) forms was historically and politically "reasonable."

Part III examines the literature seeking to explain this judgment of "reasonableness". Joy herself suggested that the actions of the National Registration Department (NRD) charged with issuing national ID cards that listed one's religious identity-actions closely tied to the statutory lacuna mentioned above-were a "trick" designed to prevent any official

${ }^{16}$ Lina Joy, supra note 7 at $607-8$. 
recognition of her religious conversion. ${ }^{17}$ Others, however, trace this lacuna to an intrinsic problem within Islamic law-in effect, an intrinsic aversion within the substantive law overseen by Malaysia's state-level shari'ah courts to any form of Muslim apostasy. There is, however, a third explanation - a more explicitly political explanation - that turns away from the NRD and Malaysia's state-level shari'ah courts to explain the lacuna preventing state-based recognition for Joy's conversion. One version of this more political explanation focuses on enduring patterns of polarization between Malaysia's conservative and liberal Muslims - patterns of polarization in which policy-makers and judges fear that any effort to confront the issue of Muslim apostasy in Malaysia's Federal Territories (via legislation) might provoke violent clashes. ${ }^{18}$ Others have argued that the lacuna frustrating Lina Joy's quest for state-based recognition merely reflects a politically motivated effort to appease, not Muslims, but non-Muslims. Here, special attention has been paid to the work of those seeking to prevent the legal prohibition of Muslim apostasy, noting that such a prohibition would merely prevent erstwhile non-Muslims who had converted to Islam from reverting back to their original faith. ${ }^{19}$

After considering these alternative explanations for the procedural lacuna that frustrated Lina Joy, we draw on specific features of Malaysia's constitutional and political history to flesh out a set of Malaysian ideas about what constitutes a "reasonable" set of administrative procedures governing Muslim apostasy within Malaysia's constitutional order. In particular, we highlight a number of empirical variables linking fundamental rights to the historical and political contingencies underpinning Malaysian modes of formal state recognition for religious identity. We do not set aside the issue of fundamental rights - already examined at some length in the existing literature. Instead, we argue that an historically and politically nuanced understanding of administrative "reasonableness" in Malaysia is essential for those with an interest in the operationalization of fundamental rights in the case of Lina Joy.

In Malaysia, the Federal Court insisted that specific bureaucratic procedures-procedures grounded in deeply contextualized notions of administrative "reasonableness" - need not imply a total denial of constitutionally protected religious liberty. In fact the Chief Justice who delivered the majority decision did not categorically reject the possibility of a Muslim's renunciation of Islam; he merely suggested that any person seeking to leave Islam must follow the relevant procedures. ${ }^{20}$ In short, he noted that religious freedom was protected so long as each actor-elected representatives, bureaucratic officials, and private citizens - followed the rules set out to create (and adhere to) relevant procedures. Once Joy had fulfilled the procedures to renounce Islam, and the relevant Islamic authorities had "authorized" her apostasy, the Chief Justice suggested that she was free to

\footnotetext{
${ }^{17}$ Lina Joy, supra note 7 at 620.

${ }^{18}$ See Tamir Moustafa, The Politics of Religious Freedom in Malaysia, 28 Maryland J. InT'L L. 129

19 See Kikue Hamayotsu, Once a Muslim, Always a Muslim: The Politics of State Enforcement of Syariah in Contemporary Malaysia, 20 South EAst Asia Res. 399 (2012).

${ }^{20} I d$. at 618 .
} (2013). 
embrace the religion of her choice. ${ }^{21}$

Focusing on the operationalization of fundamental rights in a highly charged context shaped by religious norms, we argue that the operationalization of fundamental rights is politically contingent; it is contingent precisely insofar as it is channeled through official procedures framed by deeply contextualized notions of administrative "reasonableness." Political considerations, if you will, often underpin formal legal assessments of administrative "reasonableness" - assessments that, in turn, shape the operationalization of each state's recognition of a fundamental right to religious self-identification.

\section{CONTEXTUALIZING MUSLIM CONVERSION IN MALAYSIA}

In order to understand the legal context within which Lina Joy's effort to obtain state recognition for her religious conversion unfolded, it is necessary to grasp certain features of Malaysia's federal constitution. The British colony of Malaya achieved its independence in 1957 from a set of territories known as the Straits Settlements as well as the Federated and Unfederated Malay States. The Straits Settlements (Malacca, Penang, Singapore, and Dindings) were directly administered by the British Crown, and in those settlements the terms of Muslim personal law were closely tied to Anglo-Mohammadan law as it developed in British India. In the Federated and Unfederated Malay states, however, British representatives worked with regional sultans, who retained de jure sovereignty with respect to both Muslim law and Malay custom. 22

During Malaya's anti-colonial nationalist movement, many regional sultans were allied with United Malays National Organization (UMNO). ${ }^{23}$ And, in Malaya, this pattern of political collaboration culminated in a constitutional settlement that provided for a dual court system, separating the country's centralized "civil" courts from its state-level "Muslim" courts. Malaya was renamed Malaysia in 1963 after the removal of Singapore and, during the 1980s, the country's Muslim courts (previously known as "qadhi" or "kadi" courts) were recast as state-level "shari'ah" courts.

Departing from the postcolonial experience of South Asia, the de jure sovereignty of Malaysia's regional sultans with respect to Islamic law and the country's shari'ah courts was preserved in Malaysia's Federal Constitution, which also stipulates in Article 3 that "Islam is the religion of the Federation" 25 while, at the same time, protecting religious freedom subject to "public order" and certain other considerations. ${ }^{26}$ Initially, many of Malaya's regional sultans objected to Article 3, believing it would encroach on their religious authority within

${ }^{21}$ Id. at 612.
${ }^{22}$ Andrew Harding, Law, Government, And the Constitution in Malaysia 13 (1993).
${ }^{23}$ See generally Hari Singh, UMNO Leaders and Malay Rulers: The Erosion of a Special Relationship, 68 PaCific Affairs 187 (1995).

${ }^{24}$ Malaysia's states have three tiers of shari'ah courts: subordinate courts, high courts, and appeal courts.

${ }^{25}$ See CONST. OF MALAYSIA (1957), art. 3 (Malay.).

${ }^{26}$ See CONST. OF MALAYSIA (1957), art. 11(5) (Malay.). 
their respective states. ${ }^{27}$ However, when it was explained that Article 3 was effectively a symbolic article - indeed, that the religious authority of regional (state-level) sultans would remain firmly intact - they accepted it. ${ }^{28}$ Separate constitutional articles define the ethnic category "Malay" as composed of persons who profess Islam ${ }^{29}$ while, at the same time, providing that certain Islamic matters will be governed by state-level shari'ah courts overseen by the country's regional sultans. ${ }^{30}$ Together, these articles mean that matters concerning Islam and Muslim personal law are inextricably tied to the terms of Malaysian federalism and, thus, a delicate balance between Malaysia's central government, Malaysia's sultans, and each state-level legislature.

The jurisdiction of Malaysia's shari'ah courts is limited to matters allocated to them by the constitution and state-level legislative action. ${ }^{31}$ This legislative action, whether in the form of a legislative enactment or a fatwa issued by a state-level Mufti, is subject to approval by the relevant state-level sultan before it can be gazetted and transformed into an enforceable law. In Malaysia's Federal Territories (e.g. in the Malaysian capital of Kuala Lumpur), the pattern is similar to that in territories like Washington, D.C.: local institutions - including shari'ah courts - exist, but it is the federation that oversees them. In fact, it is not a state-level sultan but Malaysia's Yang di-Pertuan Agong (a "king" elected on a rotating basis from amongst Malaysia's regional sultans) who oversees the "state-level" shari'ah courts in Federal Territories like Kuala Lumpur. ${ }^{32}$ This point is important, because the case of Lina Joy originated in Kuala Lumpur.

\section{A. Muslim Conversion: Legal Debates}

The issue of Muslim apostasy or conversion away from Islam-pertaining both to constitutional issues like religious freedom ${ }^{33}$ and to state-level shari'ah enactments ${ }^{34}$ - was initially perched in between Malaysia's civil courts (protecting fundamental rights) and Malaysia's shari'ah courts, with the civil courts maintaining powers of judicial review. However, in 1988, a constitutional amendment (Article 121(1A)) was passed to provide the shari'ah courts with exclusive jurisdiction in matters specified under List II (Paragraph One)

${ }^{27}$ Dian A. H. Shah, "Constitutionalizing Religion and Religious Freedom: A Comparative Study of Malaysia, Indonesia, and Sri Lanka” 266 (2014) (unpublished S.J.D. dissertation, Duke University) (on file with Duke University Library).

28 Joseph M. Fernando, The Making of the Malayan Constitution 171 (2006). See also, Shah, supra note 26 at 92 .

${ }^{29}$ See CONST. OF MALAYSIA (1957), art. 160 (2).

${ }^{30}$ See CONST. OF MALAYSIA (1957), art. 74. This provision clarifies the legislative powers of Malaysia's federal and state-level governments with reference to the "federal", "state", and "concurrent" legislative lists set out in the constitution's Ninth Schedule.

${ }^{31}$ See CONST. OF MALAYSIA (1957), Ninth Schedule, List II.

${ }^{32}$ For a discussion of the legal, political, and administrative structures surrounding Islamic law in Malaysia, see Farid S. Shuaib, The Islamic Legal System in Malaysia, PACIFIC RIM L. \& PoL'y J. 85 (2012), 85 and Farid S. Shuaib, Strengthening Administrative Institutions of Islamic Law in Malaysia: An Overview, 16 JuRNAL SYARIAH 443 (2008).

${ }^{33}$ See CONST. OF MALAYSIA (1957), art.11 (Malay.).

${ }^{34}$ See CONST. OF MALAYSIA (1957), Ninth Schedule (Malay.) 
of the constitution's Ninth Schedule (namely, the personal and family law of persons professing the religion of Islam). ${ }^{35}$ The effect of this amendment on civil court powers of judicial review has been a subject of extensive legal debate: some believe this amendment bars the civil courts from reviewing shari'ah-court judgments; others insist that the civil courts retain such powers, particularly in cases involving an interpretion of constitutional provisions.

Even apart from this amendment, however, there are federal statutory limits on the punitive powers of Malaysia's state-level shari'ah courts: up to three years imprisonment, fines of MYR5000, and six lashes. ${ }^{37}$ Although cases of Muslim apostasy are handled by Malaysia's state-level shari'ah courts (including those in the Federal Territories), then, those courts are not able to impose capital punishment. ${ }^{38}$ In fact, even before Lina Joy, Malaysia's Supreme Court (now Federal Court) declared that, with reference to Muslim apostasy, each state legislature was required to define a state-level shari'ah-court procedure to govern the process - up to and including discretionary efforts to deter apostasy within state-level punitive limits. $^{39}$ If states failed to specify any applicable procedure, the Court held that this did not actually prohibit Muslim apostasy; instead, the Court noted that recalcitrant state legislatures (or, in the Federal Territories, parliament itself) were still required to frame statutory rules for their sultans (or the king) to endorse. This ruling stemmed from the fact that, according to the constitution's Ninth Schedule, explicit legislation was required to endow state-level shari'ah courts with jurisdiction over issues mentioned in the state-level legislative list. Even then, state-level legislatures did not have the authority to enact just any

${ }^{35}$ See CONST. OF MALAYSIA (1957), art, 121-1A and Ninth Schedule (Malay.) List II (Paragraph One) describes the jurisdiction of states: It covers, "[e]xcept with respect to the Federal Territories of Kuala Lumpur, Labuan, and Putrajaya, [the] Islamic law and personal and family law of persons professing the religion of Islam, including the ... creation and punishment of offences by persons professing the religion of Islam against precepts of that religion, except in regard to matters included in the Federal List; [as well as] the constitution, organisation and procedure of Syariah courts, which shall have jurisdiction only over persons professing the religion of Islam and in respect only of any of the matters included in this paragraph, but shall not have jurisdiction in respect of offences except in so far as conferred by federal law [...]."

${ }^{36}$ See Andrew Harding, The Constitution of Malaysia: A Contextual Analysis 203 (2012); Shad

Saleem Faruqi, Document of Destiny: The Constitution of the Federation of Malaysia (2008); Lina Joy, supra note 7 at 630 (dissenting opinion of Justice Richard Malanjum).

${ }^{37}$ Syariah Courts (Criminal Jurisdiction) Act 1965.

${ }^{38}$ Within Islamic law, the punishment for apostasy is debated. This issue is not explicitly addressed in the Qu'ran; it emerges in various hadith (sayings of the Prophet Mohammad), and historically different "schools" of Muslim jurisprudence have stressed different punishments. See generally, Frank Griffel, Toleration and Exclusion: Al-Shafi'i and al-Ghazali on the Treatment of Apostates, 84(3) Bulletin of SOAS 339 (2001), and Yohannan Friedmann, Tolerance and Coercion in Islam: Interfaith Relations in the Muslim Tradition 121-59 (2003). In 1990 Kelantan's Chief Minister (PAS) pressed for the imposition of capital punishment. UMNO suggested a constitutional amendment to enhance the jurisdiction of state-level courts (thereby avoiding accusations of standing in the way of shari'ah); but this idea was later withdrawn. See Andrew Harding, The Keris, the Crescent and the Blind Goddess: The State, Islam and the Constitution in Malaysia, 6 SingAPORE J. INT'L \& Comp. L. 154, 176-7 (2002).

39 See generally, Dalip Kaur v Pegawai Polis Daerah, Balai Polis Daerah, Bukit Mertajam \& Another, 1 Malay. L. J. 1 (1992). 
law pertaining to Islam; they were limited to Islamic matters spelled out in Paragraph One of List II. ${ }^{40}$ Without enabling legislation, in other words, Article 121-1A was not sufficient, on its own, to empower or guide the procedural action of Malaysia's state-level shari'ah courts.

Since 1988, however, several court cases have sought to clarify the relationship between Malaysia's federal structure and the question of fundamental rights (with particular reference to the question of Muslim apostasy). These cases framed the environment within which Lina Joy emerged.

In 1991, the High Court was asked to decide whether a person from Selangor who had allegedly converted to Islam had died as a Muslim. ${ }^{41}$ The Court concluded that, because neither the Selangor Administration of Muslim Law Enactment (1952) nor the Islamic Family Law (Federal Territories) Act (1984) specifically mentioned the issue of conversion-in other words, because there was no explicit legislation endowing Selangor's shari'ah courts with jurisdiction over this issue - the matter should be heard by a (civil) High Court instead. ${ }^{42}$ However, in 1992, this view was modified in the case of Dalip Kaur, a case concerning the status of a man from Kedah who was said to have converted out of Islam before he passed away. $^{43}$ In this case, the Supreme Court declared that the civil courts could not assume jurisdiction, because matters of Muslim apostasy required a detailed assessment by a qualified religious authority. ${ }^{44}$ Still, the Kedah Administration of Muslim Law Enactment (1952) did not clarify the procedural mechanism whereby Muslims might leave Islam (indeed, there was no explicit legislation clarifying the jurisdiction of Kedah's shari'ah courts in cases of Muslim apostasy at all) so, in the end, the Court found that Kedah's civil courts were, by default, empowered to render a binding decision. ${ }^{45}$

In 1998, however, the High Court adopted an entirely different approach, holding in Mohammad Hakim Lee ${ }^{46}$ that, even where explicit state-level legislation conferring jurisdiction on state-level shari'ah courts in matters of Muslim apostasy did not exist, there was no justification for granting default jurisdiction to the civil courts. ${ }^{47}$ On the contrary, according to Idrus Bin Harun (a parliamentary draftsman in the office of the Malaysian Attorney General), Md Hakim Lee held that jurisdiction in matters of Muslim apostasy lay with state-level shari'ah courts given their jurisdiction over Muslim religious affairs (as per Article 121-1A), "even if no express provisions were provided in [a state-level statute]." Muslim apostasy was left to state-level shari'ah courts, in other words, on the expectation that

\footnotetext{
${ }^{40}$ FARUQI, supra note 34 at 134 .

${ }^{41} \mathrm{Ng}$ Wan Chan v. Majlis Ugama Islam Wilayah Persekutuan \& Another (No 2) 1 MaLAY. L. J. 487 (1991)

${ }^{42} I d$. at 490 .

${ }^{43}$ Dalip Kaur, supra note 39.

${ }^{44} I d$. at 9 (concurring opinion by Justice Mohamed Yusoff).

${ }^{45} \mathrm{Id}$. at 7 .

${ }^{46}$ Md Hakim Lee v. Majlis Agama Islam Wilayah Persekutuan, Kuala Lumpur, 1 Malay. L. J. 681 (1998)

${ }^{47}$ Id. at 689.

${ }^{48}$ Dato Idrus bin Harun, "Interaction between Syariah Law and Civil Law." Paper presented at the Inaugural Annual Events (IAE) of the AGCs, March 23 - 25, 2006, Singapore.
} 
explicit legislative guidance regarding appropriate procedures would emerge at a later date: "The fact that the plaintiff might not have [an explicit] remedy in the syariah courts," noted Harun, "would not make the jurisdiction exercisable by [a civil] High Court.",49

This view was later reinforced in a landmark case known as Soon Singh, ${ }^{50}$ wherein it was found that although each state (including the Federal Territories) had explicit laws covering conversion to Islam, only some had provided their shari'ah courts with explicit jurisdiction over conversions away from Islam. ${ }^{51}$ In Soon Singh, however, the Federal Court concluded that, in cases of Muslim apostasy, the jurisdiction of state-level shari'ah courts could be implied given the special religious expertise required to judge such cases. ${ }^{52}$ This approach was expanded in a subsequent case known as Shaik Zolkaffily, ${ }^{53}$ where the Federal Court held that if jurisdiction over a specific issue had been conferred upon the shari'ah courts - either explicitly or implicitly_-but no legal remedy had been specified within those courts, it was nevertheless for the state legislature to outline a remedy within the shari'ah courts. $^{54}$ In other words, recalling Md Hakim Lee, "the fact that [a litigant] did not have his remedy in the syariah court would not make the jurisdiction exercisable by the civil court." This is the jurisprudential background that set the stage for Lina Joy.

During the 1980s and 1990s several states introduced legislation specifying a procedure concerning Muslim apostasy to be overseen by their state-level shari'ah courts. In Pahang, Perak, Malacca, and Sabah, these enactments identified Muslim apostasy as an offense (e.g. an insult to Islam) to be punished with fines and/or imprisonment. ${ }^{56}$ By contrast, in Negeri Sembilan, steps were put in place allowing state-level shari'ah courts to oversee the process of Muslim apostasy (including three months of counselling and a further cooling-off period of one year) before a certificate of conversion was issued. ${ }^{57}$ And, in Johor, the unreported case of Ismail bin Suppiah ${ }^{58}$ noted that, as per the (now-repealed) Johor Administration of Islamic Law Enactment (1978), the chief kadi was expected to play a purely mechanical role in registering the new name of any Johor-based Muslim who declared him or herself an apostate. ${ }^{59}$ In the Federal Territories and at least four other states, however, the issue of Muslim apostasy was not addressed at all. The question is: why did this statutory (and, thus, procedural) lacuna persist and, moreover, why were the actions of bureaucratic officials requiring would-be converts to complete the procedures left missing by this lacuna
${ }^{49} I d$.
${ }^{50}$ Soon Singh v. Pertubuhan Kebajikan Islam Malaysia (PERKIM) Kedah, 1 MaLAy. L. J. 489 (1999).
${ }^{51} \mathrm{Id}$. at 501 .
${ }^{52} \mathrm{Id}$. at 502.
${ }^{53}$ Majlis Ugama Islam Pulau Pinang dan Seberang Perai v Shaik Zolkaffily bin Shaik Natar \& Others, 3 Malay. L. J. 705 (2003).

${ }^{54} \mathrm{Id}$. at 719.

${ }^{55} \mathrm{Id}$.

56 See, for e.g., Crimes (Syariah) Enactment 1992 (Enactment No. 3 of 1992), ss. 12 and 13, Administration of the Religion of Islam and the Malay Custom of Pahang Enactment 1982, ss. 103 and 185.

${ }^{57}$ Administration of the Religion of Islam (Negeri Sembilan) Enactment 2003, s. 119.

${ }^{58}$ Ismail bin Suppiah v Ketua Pengarah Pendaftaran Negara (R-1-24-31-95) (unreported case).

${ }^{59}$ See the Johor Faith Protection Bill 2000, which resembled a bill passed that year in Perlis. 
seen as legally "reasonable"?

\section{B. Muslim Conversion: Political Debates}

Apart from this jurisprudential and legislative context, it is important to appreciate the larger political context within which cases of Muslim apostasy were addressed. Here, much depends on the electoral competition between two leading parties in Malaysia: the right-of-center United Malays National Organization (UMNO) - the dominant collaborator in a ruling coalition known as the Barisan Nasional (BN) or National Front - and the religiously conservative Parti Islam Se-Malaysia (PAS). Since its inception in the early 1950s, PAS has projected itself as the only truly "Islamic" party in Malaysia. ${ }^{60}$ In fact, for much of the country's history, and especially since the late 1970s when social and political movements took on a more overtly religious character, UMNO and PAS have competed for Muslim "religious" votes - especially in the north and east of the country (Malaysia's Malay-Muslim "heartland"). ${ }^{61}$ Central to this competition has been a push to construct a cohesive Muslim constituency by "defending" the boundaries of Islam or at least appearing to defend Muslim interests. In effect, UMNO and PAS have sought to "out-Islamize" one another by highlighting issues that touch on Muslim religious sensitivities. ${ }^{62}$

This competitive religious-cum-political posture stretches from policing various forms of religious orthodoxy to discouraging Muslim apostasy. The government's emphasis on Islam, for instance, was officially expressed during UMNO's 1982 General Assembly, when Prime Minister Mahathir Mohamad stressed that UMNO would ensure Malay-Muslim adherence to various Islamic teachings. ${ }^{63}$ In fact, certain reform initiatives took place even before Mahathir assumed office: at the federal level, the government established a National Council for Islamic Affairs (Pusat Islam) under the Department of Religion-a council that was later placed in the office of Prime Minister Mahathir as the Department for Islamic Development (JAKIM).

Within Malaysia, each state maintains its own Islamic affairs department. However, JAKIM has become increasingly influential in coordinating inter-state Muslim affairs (particularly insofar as states have become more and more reliant on funds derived from the centre). ${ }^{65}$ JAKIM recommends draft laws for enactment at the level of each state and plays an important role in ongoing efforts to standardize Islamic law throughout the country. Theoretically, each state legislature as well as the Majlis Raja-Raja (Conference of Rulers) is entitled to ignore JAKIM's advice-in fact, in 2001, when the Majlis Raja-Raja was consulted regarding JAKIM's harmonization efforts, it accepted JAKIM's suggestions in

${ }^{60}$ Andrew Harding, Sharia and National Law in Malaysia, in Sharia InCorPorated: A Comparative Overview of the Legal Systems of Twelve Muslim Countries in Past and Present 491, 502-3 (Jan Michiel Otto ed., 2010)

${ }^{61}$ Shah, supra note 26 at 344.

${ }^{62} \mathrm{Id}$. at 386.

${ }^{63}$ Gordon P. Means, Political Islam in Southeast Asia 126 (2009).

${ }^{64} I d$.

${ }^{65}$ See Maznah Mohamad, The Ascendance of Bureaucratic Islam and the Secularization of the Sharia in Malaysia, 83 PACIFIC Affairs 505, 505 (2010). 
several areas except Islamic criminal law. ${ }^{66}$ In practice, however, given its persistent political dominance, both at a federal level and in several Malaysian states throughout the 1980s, 1990s, and early 2000s (except in Kelantan, where PAS won state-level elections in 1990), the ruling BN working with JAKIM has found it relatively easy to encourage various forms of standardization in state-level laws related to the terms of Islam. Even within Malaysia's federalized approach to Islam, in other words, close links between federal and state-level party politics have ensured that many shari'ah-based policies have been slowly harmonised over time. Still, the question remains: why did accelerating patterns of standardization fail to touch sensitive "criminal" issues like Muslim apostasy? And, turning to the operationalization of human rights, why was the procedural lacuna left by this failure, in Kuala Lumpur, considered legally "reasonable"?

\section{UNDERSTANDING LINA JOY: FROM FUNDAMENTAL RIGHTS TO ADMINISTRATIVE "REASONABLENESS"}

By the time Lina Joy reached Malaysia's Court of Appeal and, then, the Federal Court, Joy's quest to obtain state recognition for her religious conversion-by deleting the word "Islam" from her national ID card - was clearly framed as a case of administrative law rather than fundamental rights. The facts were simple. Initially, Azalina binti Jailani (a.k.a. "Lina Joy") applied to change the name on her ID card (which did not mention her religion), stating the reason for this change as a "change of religion" from Islam to Christianity. Her application, however, was denied, and Joy was advised to apply again stating that the reason for her change of name was her "choice" of religion. This time her request was granted, and she received a new ID card bearing her new name.

Unfortunately, this new ID card also included her old name on the back. And, owing to a legislative amendment that came into effect while Joy's application for a new ID card was being processed, her new card also described her religion as "Islam". (The intervening piece of legislation specified that every national ID card must specify a Muslim's religion as Islam; and, along the way, the National Registration Department [NRD] claimed that, while it recognized Joy's new name, it had no authoritative documentary evidence stating that she had renounced Islam. ${ }^{67}$ ) When Joy later applied to delete the word "Islam" from her ID card, she was ordered to follow the procedures spelled out in Malaysia's National Registration Regulations 1990 (hereinafter, the "1990 Regulations"), which provided her with a set of forms requiring any Muslim applying for a change of name to specify their religion and, then, to provide "[a]ny further documentary evidence as the registration officer may consider necessary to support the accuracy of any particulars submitted." ${ }^{68}$

When Joy submitted her forms specifying her religion as "Kristian" (along with a copy of her baptismal certificate), the presiding NRD officer made a notation saying that the

\footnotetext{
${ }^{66}$ Means, supra note 58 at 126.

${ }^{67}$ The same piece of legislation specified that, amongst the "reasons" given by those seeking to change their name, "change of religion" was no longer permitted.

${ }^{68}$ National Registration Regulations 1990, clause 4(c)(x).
} 
religion of the applicant should be retained as Islam because, scanning the NRD records, there was no authoritative documentary evidence stating that, before Joy became a Christian, she had officially abandoned Islam. ${ }^{69}$ As in the case of London's Jewish Free School, a mere assertion of religious identity by a private citizen (or, for that matter, a recognized religious authority - in this case, the church issuing Joy's baptismal certificate) was not enough. Instead, the state required a three-way combination of individual self-assertion (i.e. individual profession), acknowledgement by a relevant religious authority (insofar each religious community in Malaysia was constitutionally entitled to "regulate its own affairs"), and above all, some type of formal procedure administered by the state itself. In Malaysia, following the "implied" jurisdiction of the state-level shari'ah courts spelled out in Soon Singh, it was this last element that figured most prominently in the case of Lina Joy.

Joy insisted that, as per the form she was asked to complete, her baptismal certificate was sufficient to support "[t]he accuracy of any particulars submitted," actually submitted concerned her status as a Christian. However, the NRD contended that, insofar as Joy was seeking to delete the word Islam from her ID card (and, thus, to change her status from what was in the NRD records), the only satisfactory evidence was a certificate of apostasy from a state-level shari'ah court, a state-level Islamic Council, or a state-level

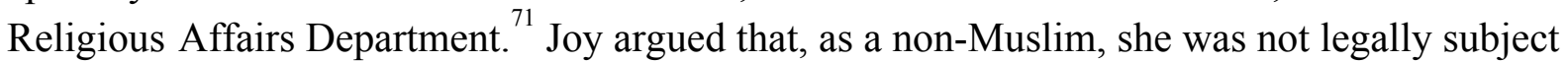
to the jurisdiction of shari'ah courts. However, the NRD argued that it was not her professed status as a Kristian but her earlier effort to abandon Islam that was at issue (in deleting the word "Islam"). As such, the NRD argued that the procedure for adjudicating this act of renunciation - by implication, since the Administration of Islamic Law (Federal Territories) Act (1993) did not explicitly mention Muslim apostasy-involved the work of a shari'ah court. $^{72}$

In effect, recalling many of the cases balancing administrative procedures and fundamental rights in Europe or the U.K., the question before the Court became one involving a routine matter of administrative law, albeit one that underpinned the operationalization of a basic right. In Malaysia, however, the question was not subject to a test of "proportionality" (as it might have been in Europe or the U.K.). Instead it was subject to a test of Wednesbury "unreasonableness": Did the NRD act "unreasonably" and beyond

\footnotetext{
${ }^{69}$ Lina Joy v. Majlis Agama Islam Wilayah Persekutuan and Others, 6 Malay. L. J. 193, 202 (2005).

${ }^{70}$ Lina Joy, supra note 7 at 629.

${ }^{71}$ Lina Joy, supra note 7 at 627. See also, Mohamed Azam Mohamed Adil, Law of Apostasy and
} Freedom of Religion in Malaysia, 2(1) Asian J. Comp. L. (2007).

${ }^{72}$ For analogous considerations regarding administrative law (and its implications for the protection of rights) in an American context, see Jerry L. Mashaw, Between Facts and Law: Agency Statutory Interpretation as an Autonomous Enterprise, 55 Univ. Toronto L. J. 497 (2005) and Cass R. Sunstein, Law and Administration after Chevron, 90 Columbia L. R. 969 (1990). For arguments focusing on administrative law and fundamental rights in the British context, see M.C. Tolley, Judicial Review of Agency Interpretation of Statutes: Deference Doctrines in Comparative Perspective, 31 PoL'y STUD. J. 421 (2003); Poole, supra note 4; and Jowell, supra note 9. For arguments pressing for a more robust effort to protect individual religious freedom rights than the turn to proportionality has so far allowed, see Nicholas Gibson, Faith in the Courts: Religious Dress and Human Rights, 66(3) CAMBridge L. J. 657 (2007). 
the parameters of its administrative discretion when it required Joy to obtain a certificate of apostasy from the shari'ah court before deleting the word Islam from her ID card? In fact, when it arrived in the Federal Court, this case was explicitly framed as a case of Wednesbury unreasonableness, asking whether the decision taken by the NRD was wrong, capricious, perverse, or absurd - indeed, "[s]o unreasonable that no reasonable authority could have ... come to it." 73

The Federal Court, by a 2:1 majority, concurred with the Court of Appeal and concluded that the NRD had acted reasonably for at least three reasons. ${ }^{74}$ First, the majority argued that the NRD's insistence on authoritative evidence from the shari'ah court confirming that Joy was no longer a Muslim was "reasonable." " In particular, the Chief Justice argued that a simple declaration issued by a person leaving the religion was not enough. $^{76}$ Because renouncing Islam implicated the terms of Islamic law, it was perfectly reasonable for the NRD to require confirmation from Islamic authorities who were thought (by the state) to possess the expertise required to adjudicate such matters. ${ }^{77}$ In fact the Court added that, if the NRD had simply accepted a person's "self-declaration", the NRD might risk "wrongly" designating a person's religious affiliation.

Second, agreeing with the Court of Appeal, the Federal Court conceded that the relevant Administration of Islamic Law (Federal Territories) Act (1993) granting jurisdiction to Kuala Lumpur's shari'ah courts did not provide any guidance regarding the procedures governing Muslim apostasy. Yet, following Soon Singh, the Court declared that the jurisdiction of the shari'ah courts was still implied. ${ }^{79}$ In fact, as per Md Hakim Lee, all three justices accepted the view that the judiciary must avoid legislating on its own; the courts were simply obliged to encourage each state-level legislature to satisfy its legal role in specifying the relevant procedures. ${ }^{80}$ In effect, the Court argued that it was "reasonable" to expect each actor within Malaysia's constitutionally defined legal-cum-administrative apparatus to play its required part. The alternative-i.e. arrogating legislative powers to the Federal Court on the premise that a radical commitment to institutional centralization was required to ensure a defense of fundamental rights - was rejected, because such a move was seen as undermining, not only the separation of powers, but also the federalized underpinnings of Malaysia's constitutional approach to religion. ${ }^{81}$

Third, it is important to stress that the 1990 Regulations did not offer any clear

\footnotetext{
${ }^{73}$ Associated Provincial Picture Houses Ltd. v Wednesbury Corporation 1 K.B. 223 (1948) at 234.

${ }^{74}$ This split decision reflects what Joshua Neoh has called "Islamic" and "common-law" constitutional-ism in Malaysia. See Neoh, supra note 9.

${ }^{75}$ Lina Joy, supra note 3 at 604.

${ }^{76} I d$.

${ }^{77}$ For a related account focusing on judicial deference to specialist competencies, see Jeffrey Jowell, Judicial Deference and Human Rights: A Question of Competence, in LAW ANd Administration IN EURope 68 (Paul Craig and Richard Rawlings, eds., 2003).

${ }^{78}$ Lina Joy, supra note 3 at 603.

${ }^{79} I d$. at 616-18.

${ }^{80} \mathrm{Id}$.

${ }^{81}$ Lina Joy, supra note 7 at 618.
} 
guidance as to what must be provided to correct erroneous particulars on an ID card. Instead, the Court declared that it was within the discretion of each NRD officer to determine which documentary evidence was required "[t]o support the accuracy of any particulars submitted" and that, in cases of Muslim apostasy, it was entirely "reasonable" in light of prevailing jurisprudence to expect some type of certification from Malaysia's state-level shari'ah courts.

${ }^{83}$ The Court stressed that determining the question of whether a person had renounced Islam was not something "[t]he NRD is ... equipped or qualified to decide." ${ }^{84}$ In fact, the Court opined that, even when a certificate of apostasy was furnished before the NRD, each NRD officer still possessed the discretion to retain or remove the word "Islam" from an ID card. In Lina Joy, the relationship between fundamental rights and administrative discretion (and the limitation of judicial interference vis-à-vis that discretion) was made abundantly clear.

As noted above, the Court did not explicitly state that Lina Joy could not change her religion (in keeping with the fundamental rights outlined in Article 11 of the constitution). On the contrary, the Court simply concluded that Joy's exercise of a right to religious identity was subject to the relevant regulations. ${ }^{86}$ In short, the exercise of one's fundamental rights under Article 11 (as a Muslim) could not occur unless specific procedures associated with the renunciation of Islam were followed-procedures closely tied to Malaysia's federal constitutional order and the authority of its state-level shari'ah courts.

\section{LINA JOY: RIGHTS VS. REASONABLENESS?}

Initially, Lina Joy argued that the NRD's actions amounted to a form of trickery to prevent any state recognition of her conversion. In her submission at trial (in the High Court), Joy documented her interactions with the NRD: the NRD had rejected-without providing any reason-her first application for a change of name (explaining that she had renounced Islam), but when she put in a second application almost two years later (again citing her conversion), the NRD did not respond. ${ }^{87}$ She subsequently enquired about the status of her application, whereupon she was told not to disclose her conversion to avoid any difficulty, so she submitted a third application, which was approved but with a new ID card specifying her religion as "Islam." attention to this series of interactions. In fact, while addressing the issue of "reasonableness," Malanjum argued that, within the terms of Malaysia's existing policy framework, Joy had been faced with an impossible requirement.

\section{A. Proceduralizing Apostasy}

\footnotetext{
${ }^{82} \mathrm{Id}$. at 603.

${ }^{83} \mathrm{Id}$. at 604.

${ }^{84} \mathrm{Id}$. at 602.

${ }^{85} \mathrm{Id}$. at 604.

${ }^{86} \mathrm{Id}$. at 612 .

${ }^{87} \mathrm{Id}$. at 620.

${ }^{88} \mathrm{Id}$. at 621 .
} 
Malanjum began his dissenting judgment by accepting that the NRD official who handled Joy's case was entitled to request any documentary evidence "[n]ecessary to support the accuracy of any particulars submitted." submitted concerned Joy's identity as a Christian - hence her baptismal certificate - rather than her status as an ex-Muslim. There was an "abuse of power," he noted, when the NRD "[f]ailed to take into consideration a legally relevant factor, namely ... the documents submitted by the appellant, ... preferring [instead] its policy of requiring a certificate of apostasy from the Federal Territory Syariah Court." This policy, according to Malanjum, was not stipulated in the 1990 Regulations. Moreover, turning to the question of Wednesbury "unreasonableness", he also drew attention to the matter of completing a set of forms that did not yet exist. For Malanjum, the NRD's insistence on a certificate of apostasy from the Federal Territory Syariah Court was not only illegal but unreasonable, "[b]ecause under the applicable [legislation], the Syariah Court in the Federal Territory has no statutory power to adjudicate on the issue of apostasy." In short, he noted, the NRD "[r]equired the performance of an act that was almost impossible to perform." 92

This statutory lacuna pertaining to the jurisdiction of the Federal Territory’s shari'ah courts in matters of Muslim apostasy thus became the central issue in Lina Joy. Did the NRD exercise its administrative discretion in a "reasonable" manner when it sought to chart a course between (a) the statutory silence of the Administration of Islamic Law (Federal Territories) Act (1993) and (b) the guiding jurisprudence of Soon Singh regarding the implied jurisdiction of the Federal Territory's shari'ah courts?

Malanjum, like his colleagues on the bench, did not seek to erase the silence of the Federal Territories by legislating from the bench; instead, he adhered to the work of his predecessors in continuing to press for clearly defined laws in each state. In particular, he stressed that, in matters restricting constitutional rights, jurisdiction must not be "implied". Quoting the Chief Justice in Dalip Kaur (1997), he prioritized questions of policy-making and emphasized that, in light of the 1988 constitutional amendment to Article 121, clearly defined procedural guidance should be incorporated "[i]n all state enactments to avoid [any] difficulties of interpretation by the civil courts." ${ }^{, 94}$ Indeed, even as Justice Malanjum sought to stress a more substantive pattern of protection for the fundamental rights outlined in Malaysia's constitution, he found it difficult to encroach upon the prerogatives of state-level legislative power.

It is worth noting that Malanjum sharply differed from his colleagues on the bench regarding the way in which this case should be approached. Even though he engaged with

${ }^{89} I d$. at 626. Unlike his colleagues who delivered the majority judgment, Malanjum emphasized that this case involved, first and foremost, crucial constitutional law questions, Hence, he argued that "[b]efore it can be said that a policy is reasonable within the test of Wednesbury, its constitutionality must be first considered." $I d$, at 631 .
${ }^{90} I d$. at 630 .
${ }^{91} I d$. at 632 .
${ }^{92} \mathrm{Id}$.
${ }^{93} \mathrm{Id}$. at 636.
${ }^{94} I d$. at 635 . 
questions on reasonableness, he argued that the majority had erred in considering the issue of reasonableness, arguing that this issue should "not have been there in the first place". For Malanjum, a constitutional question must be given priority over, and independent of, any "reasonableness" determination. Indeed, one of the most common frustrations with respect to Malaysia's fundamental rights jurisprudence lies in the degree to which Malaysia's courts have opted to side-step substantive reviews focusing on the constitutionality of decisions restricting fundamental rights, engaging such cases on an administrative level by invoking a Wednesbury test instead (thus reinforcing a pattern of judicial deference to executive practices).

In any case, one of the most important political questions to emerge from Lina Joy concerned the extent to which various jurisdictions, including the Federal Territories, should be compelled by the judiciary to confront the issue of Muslim apostasy via explicit state-level enactments and, beyond this, the extent to which policies in the Federal Territories should reflect any particular procedural standard. Indeed, if at all Malaysia's federal states were to reflect such a standard, which standard could be said to reflect a "reasonable" method for regulating (and recognizing) apostasy?

Focusing on the punitive procedures in states like Kelantan, some perceived a basic religious aversion to any legalization of Muslim apostasy. Former Australian High Court Judge Michael Kirby and Malaysian scholars like Nurjaanah Abdullah, for instance, read Lina Joy's emphasis on the power of state-level shari'ah courts as, prima facie, a denial of fundamental rights. In order to protect fundamental rights, they noted, cases regarding Muslim apostasy must be removed from the shari'ah courts and returned to the civil courts forthwith. ${ }^{96}$ The problem lay in the fact that it was virtually impossible to get the required validation from a shari'ah court, as references to such courts were "not merely an administrative or procedural requirement ... [but a] control mechanism over individuals who wish to renounce [Islam]." ${ }^{97}$ Brushing past questions of administrative procedure, Abdullah added that the very existence of cumbersome shari'ah court procedures was inappropriate in religious freedom cases, as such procedures often willfully "ignore ... the reality that whether or not a person has renounced Islam is ... a question of fact [and] not of law."

This notion - that state recognition should be based strictly on one's private autonomy to choose his or her religion - is, however, rather unusual and, indeed, somewhat problematic at the level of state-based policy-making. Even apart from their primary focus on questions of administrative "reasonableness," for instance, the majority in Lina Joy described various problems with this view, arguing that it might allow Muslims to renounce Islam merely to avoid certain burdens associated with Muslim personal law (e.g. constraints on the production of a will excluding certain heirs). A more nuanced view was, however, articulated by the then Chief Justice in Dalip Kaur who, seemingly mirroring the (now defunct) procedure in Johor,

\footnotetext{
$95 \quad$ Id. at 631 .

${ }^{96}$ See Michael Kirby, Fundamental Human Rights and Religious Apostasy: The Malaysian Case of Lina Joy, 17(1) Griffith L. REv. 151, 156 (2008); Abdullah, supra note 1 at 281.

${ }^{97}$ Abdullah supra note 1 at 283.

${ }^{98} I d$.
} 
noted that state enactments could simply impose an obligation on religious authorities to maintain a register of converts. ${ }^{99}$ Yet another approach has been adopted in Negeri Sembilan, where would-be apostates are required to attend three months of rehabilitative counseling followed by a one-year cooling-off period (to reconsider) before receiving an official certificate of apostasy issued by the relevant shari'ah court.

These different approaches to proceduralizing Muslim apostasy within Malaysia's shari'ah-based courts—stretching from "punitive" Kelantan to "permissive" Negeri Sembilan-are important when it comes to considering what sort of state-level enactments could be introduced to move beyond the "implied" jurisdiction (Soon Singh) that bedeviled Lina Joy in Malaysia's Federal Territories. However, as comparative examples, they also fail to answer the central political question: why did Malaysia's Federal Territories persist in failing to specify any procedure pertaining to Muslim apostasy at all?

\section{B. Regulating Apostasy: The Political Dimension}

The last time state-level apostasy laws were enacted in Malaysia was in 2003 - in PAS-controlled Terengganu and in BN-controlled Negeri Sembilan. ${ }^{100}$ The former criminalized Muslim apostasy and attempted to prescribe the death penalty (a penalty that could not be enforced given federal statutory limits on state-level shari'ah criminal punishments); the latter specified a process allowing Muslims to leave Islam with the certification of a state-level shari'ah-court after various "rehabilitative" efforts were concluded. There were, however, other efforts to introduce apostasy regulations in Malaysia, including earlier efforts by the federal government and the state of Perlis in $2000{ }^{101}$ In these two cases, the relevant bills fell through. The federal government's proposal (which resembled the "permissive" procedures in Negeri Sembilan) never reached the floor of parliament for debate. And, in BN-controlled Perlis, a similar bill (specifying one year of rehabilitative detention rather than 30 days) was passed only to be withdrawn shortly thereafter on orders from the federal government. ${ }^{102}$ Some felt that these proposals were too "soft" on apostates, but a deeper understanding of the federal government's approach to apostasy legislation - precisely the sort of legislation needed to fill up the statutory and administrative lacuna faced by Lina Joy-requires some appreciation for the larger political context within which the government had to act.

During the 1999 general election, the BN coalition lost significant support from its

\section{${ }^{99} I d$. at 635.}

${ }^{100}$ See Section 26 of the Syariah Criminal Offence (Hudud and Qisas) Enactment 2003 (Terengganu); and, before this, Section 23 of the Syariah Criminal Code (II) Enactment 1993 (Kelantan).

${ }^{101}$ Mohd Azam Mohd Adil, Punishment for Apostasy: Conflict Between the Right to Freedom of Religion and Criminal Sentence, A Case study in Malaysia, 1 (2) JuRnal CITU 177, 189-90 (2005).

${ }^{102} I d$. at 190. The federal "Restoration of Faith Bill" required shari'ah court judges to advise would-be converts to repent, failing which they would be detained at a rehabilitation centre for up to thirty days. (If this failed, the judge would issue a declaration that the individual was no longer a Muslim.) See Santha Oorjitham, $A$ Matter of Personal Faith? Concern Grows Over an "Islamizing" Trend, AsIAwEEK.COM, http://edition.cnn.com/ASIANOW/asiaweek/magazine/2000/1013/nat.malaysia.html (accessed August 31, 2015). 
Malay Muslim constituents (particularly in the Malay Muslim heartlands), leaving UMNO struggling to decide whether it should (a) articulate more restrictive policies concerning Muslim apostasy in a push to out-flank the conservative religious positions emphasized by PAS — consider the law later enacted in Terengganu (which PAS won in 1999) — or (b) stick to the moderate image of Islam championed by Prime Minister Mahathir. The shelving of the bills in Parliament and in Perlis was framed by an effort to avoid any hasty decisions on such a politically sensitive issue. Indeed, shortly after these two bills were set aside in 2000, the government launched a series of consultations to discuss Malaysia's approach to religious affairs with Muslim scholars from several different parts of the world. ${ }^{103}$

The political circumstances surrounding Joy's quest to delete the word "Islam" from her ID card clearly featured many of the issues addressed in an article by Tamir Moustafa. ${ }^{104}$ Describing the need for would-be converts to obtain a certificate of apostasy from a shari'ah court as a procedural "dead end," Moustafa turns away from the Federal Court's decision to accept this requirement (as a constitutional matter related to Malaysian federalism and the Court's reluctance to legislate from the bench), focusing, instead, on a set of political debates emerging after the Court's decision to treat this administrative requirement as "reasonable". On the one hand, he notes that so-called liberal Muslims were concerned that Malaysia's civil courts "were beginning to cede broad legal authority [to shari'ah courts], even when it meant trampling on individual rights." ${ }^{105}$ And, yet, at the same time, he notes that conservative Muslims believed that Lina Joy's claims threatened "the Muslim community's [constitutional] ability to manage its own religious affairs" within the context of Malaysia's state-level shari'ah courts. ${ }^{106}$ The central tension, he argues, lay in the fact that Muslim liberals saw all administrative regulations pertaining to conversion as a violation of fundamental rights, whereas Muslim conservatives believed that any form of apostasy legalization threatened the integrity of their religious community. ${ }^{107}$

Moustafa's focus on post hoc polarization reveals how both sides saw the link between religious self-identification and the administrative procedures underpinning state recognition. However, he does not explain why the procedural lacuna that shaped Lina Joy's case existed in the first place; nor does he explain why the administrative barriers created by this gap were seen as "reasonable" by the courts. In fact, although the political polarization that Moustafa describes existed in many parts of Malaysia, most states actually did manage to produce some form of explicit legislation governing Muslim apostasy. Indeed, the main question pertaining to the operationalization of religious freedom in Lina Joy is: why did this policy-making process fail in Malaysia's Federal Territories (and at least four other states)?

One of the most intriguing efforts to explain this policy-based (and administrative)

${ }^{103}$ See SUARAM, Malaysian Human Rights Report: Civil and Political Rights in 2000 51-2 (2000); and Dr M: No Hasty Decision on Apostasy, New Straits Times, 30 September 2000 at 2.

${ }^{104}$ Moustafa, supra note 16.

${ }^{105} I d$. at 139.

${ }^{106} I d$. at 148.

${ }^{107}$ Ultimately, Moustafa blames the publicity surrounding Lina Joy for making earlier workarounds (allowing for the recognition of conversion by lawyers and shari'ah court judges supporting a simple change of name) more difficult. $I d$. at 151 . 
lacuna has been advanced by Kikue Hamayotsu, who asks why powerful UMNO politicians like Prime Ministers Mahathir (1981-2003), Badawi (2003-09), and Razak (2009-) chose to abandon the introduction of new apostasy laws at both the federal and the state levels despite "significant Muslim support for [apostasy] regulation" in civil society and government. ${ }^{108}$ Referring to the fact that JAKIM had proposed a new federal law seeking to regulate Muslim apostasy in 2000, Hamayotsu notes that Mahathir, Badawi, and Razak repeatedly set aside their proposal owing to "constitutional constraints and ... technical shortcomings". "In fact, she argues, they highlighted "technical" shortcomings to avoid addressing what she sees as politically divisive "core" questions concerning the status of religious freedom. ${ }^{110}$

The basis for Hamayotsu's argument rests on her contention that longstanding patterns of UMNO-PAS competition for Malay Muslim votes are not sufficient to explain the emergence (or non-emergence) of specific policies regarding the regulation of Muslim apostasy. Broadly, she notes that more attention should be paid to the finer nuances of electoral politics and, specifically, BN's growing dependence on Malaysia's non-Muslim voters. Above all, in her effort to explain the abandonment of policy initiatives concerning Muslim apostasy, Hamayotsu suggests that electoral considerations compelled UMNO to avoid introducing any "shari'ah-based" measure that might be seen as detrimental to non-Muslim (especially Chinese) interests, quoting a President of the Malaysian Chinese Association (MCA) who expressed his "rejection of Islamic law, and apostasy law in particular, being applied to [existing or erstwhile] non-Muslims." "111 In short, Hamayotsu argues that laws governing Muslim apostasy were not introduced because doing so would alienate non-Muslim voters.

Unfortunately, Hamayotsu ignores the degree to which state-level laws governing Muslim apostasy were introduced in several BN-controlled states with sizable non-Muslim populations - for example, in Sabah (35\% Chinese), Melaka (35\% Chinese), and Perak (30\%), not to mention Negeri Sembilan (23\%). In fact core features of Hamayotsu's argument do not add up in the state-level political contexts she considers. ${ }^{112}$ She also notes that Malaysia's UMNO-led federal government could have pursued harsh apostasy laws to appease its core constituency (i.e. Muslims). But, in the end, it did not. ${ }^{113}$ Evidently, the political forces underpinning the federal government's decision to avoid new legislation concerning Muslim apostasy may be more complex than Hamayotsu suggests. As we note below, the main factors may be more closely tied to an historically and politically nuanced understanding of the "constitutional" and "technical" factors Hamayotsu initially rejects.

\footnotetext{
${ }^{108}$ Hamayotsu, supra note 16 at 400.

${ }^{109} I d$. at $409-10$.

${ }^{110} I d$.

${ }^{111}$ Id. at 412. The MCA supported a set of changes in Malaysia's Marriage and Divorce Act following
} a 2007 Federal Court ruling (Subashini) in which a spouse in a civil marriage who later converted to Islam was allowed to return to the civil courts for a divorce.

${ }^{112}$ Even in the four states that failed to introduce state-level procedures governing Muslim apostasy, it is unlikely that the votes of "previously non-Muslim" Muslims were more decisive than those of "born" Muslims who found themselves in the same legal limbo.

${ }^{113}$ Hamayotsu, supra note 16 at 414. 
Before illuminating these factors, it is worth pointing out that concerns regarding non-Muslim voters may have played some role. As UMNO lost electoral ground to PAS in 1999 , it was generally non-Malay / non-Muslim voters who pulled the BN to victory. In fact the BN's success in 2004 was attributed to a return of Malay Muslim voters as well as the continued support of non-Malays. Still, this story regarding the political role played by non-Muslim voters does not extend beyond 2004. In 2008, the BN secured just $35 \%$ of all Chinese votes and 48\% of Indian votes; and, in 2013 (one year after Hamayotsu's article was published), these figures dropped to just $23 \%$ and $45 \%$, respectively, with no discernable effect on BN's approach to the regulation of Muslim apostasy. ${ }^{114}$ If Hamayotsu's argument were correct, this reduction in non-Muslim support should have allowed the BN to introduce greater restrictions on Muslim apostasy to compete more directly with PAS. It did not.

The question is: Why did the regulatory landscape surrounding Muslim apostasy remain so patchy? And, with specific reference to Lina Joy, why did this patchiness persist in the form of a statutory-cum-administrative lacuna in Malaysia's Federal Territories? This is, we argue, the key political question bearing on the administrative operationalization of religious freedom in Lina Joy. The source of this lacuna is not limited to intra-Muslim divisions or Muslim/non-Muslim divisions. Its source is tied to specific features of Malaysia's federal constitution-especially, its rather delicate balance between "federal" and "state-level" laws concerning the regulation of Islam.

\section{Regulating Apostasy: Federal-State Legal and Political Relations}

In order to explain why the introduction of specific procedures governing Muslim apostasy in Malaysia's Federal Territories was so difficult and, indeed, why the resulting administrative gap was seen as "reasonable" by Malaysia's Federal Court, we focus on the country's constitutional setup and, specifically, the rather delicate (and, to some extent, unresolved) tension between federal and state-level power, particularly in matters pertaining to religion. ${ }^{115}$

While Malaysia's scheme of federalism is center-heavy-List I of the Constitution's Ninth Schedule mentions 27 matters in which the federal parliament possesses exclusive legislative competence; List II assigns only 13 matters exclusively to the states-the first of these 13 state-level matters concerns Islamic law. ${ }^{116}$ Despite the common assumption that all "Islamic" matters are within the exclusive purview of the states, and despite the fact that state-level sultans remain the Heads of Islam in their respective state territories, however, the

${ }^{114}$ Shah quotes an UMNO Supreme Council member who explained that before the 2013 polls, the BN coalition had come to believe that non-Malay support was almost a "lost cause." Shah, supra note 23 at 385.

115 Referring to the approach adopted by the Federal Court in Lina Joy, Shah and Sani describe Malaysia's approach to the administrative procedures linking self-identification to state recognition as a "technicality". "It is frustrating for citizens who resort to the highest court in the land to uphold their rights," they write, "only to see their appeals being turned down on technicalities". Dian A. H. Shah and Mohd Azizuddin Mohd Sani, Freedom of Religion in Malaysia: A Tangled Web of Legal, Political, and Social Issues, 36 North Carolina J. Int'L L. \& Comm. Reg. 647, 655 (2011).

${ }^{116}$ See supra section I.A. 
federation's powers in matters pertaining to Islam are not entirely excluded. ${ }^{117}$ It is in fact worth recalling that the punitive jurisdiction of Malaysia's state-level shari'ah courts is capped by the federation's Syariah Courts (Criminal Jurisdiction) Act of 1965, which limits state-level shari'ah-court punishments to three years imprisonment, fines up to MYR5000, and six lashes.

List II reserves the power to create and punish offences against the precepts of Islam (including apostasy) to state legislatures and, in the case of the Federal Territories, the federal parliament. Yet, if the latter were to amend the Administration of Islamic Law (Federal Territories) Act of 1993, introducing new legislation regarding apostasy that differed from any state law - either in a more "permissive" direction like Negeri Sembilan or, together with an amendment in the Syariah Courts Jurisdiction Act of 1965, a more "punitive" direction including capital punishment (which only the federation can impose) - a number of rather awkward political questions could arise regarding the ensuing divergence of laws. To be sure, parliament can introduce laws applying exclusively to the Federal Territories; as such, federal laws in the Federal Territories do not automatically imply a push for statutory harmonization. However, politically, given the direct involvement of the federal parliament in the promulgation of such legislation and the expanding role of JAKIM, federal-state divergence is complicated. Indeed, what signal would the promulgation of federal legislation regarding Muslim apostasy send to state-level lawmakers and, more specifically, the state-level sultans recognized as the Heads of Islam in their states? ${ }^{119}$

Given the Majlis Raja-Raja's prior decision to approve forms of national standardization in all areas of Islamic law except criminal law-indeed, given the absence of any other Muslim criminal law applying exclusively to the Federal Territories - it may be that explicit parliamentary action addressing criminal cases of apostasy in the Federal Territories would be seen as an early (and threatening) indication that the federal government wanted Malaysia's sultans to move much further in the direction of "federal standards". Precisely insofar as the federal government's proposals in 2000 (resembling those of Negeri Sembilan) were considered "too permissive", it may be that, notwithstanding judicial guidance pressing for appropriate legislation in each "state-level" jurisdiction (Soon Singh; Md Hakim Lee), powerful political calculations have pushed Malaysia's parliament toward

${ }^{117}$ Laws on Islamic banking, finance, and insurance, for instance, would fall within the purview of the federal parliament.

${ }^{118}$ See Jaclyn L. Neo and Dian A. H. Shah, Hudud and the Struggle for Malaysia's Constitutional Soul, Constitutionnet, June 25, 2015, available at: http://www.constitutionnet.org/news/hudud-and-struggle-malaysias-constitutional-soul (last accessed May 5, 2016).

119 Alluding to related forms of pressure, Ramizah Wan Mohammad describes the work of JKSM, a federal department in the Prime Minister's office supporting the administration of Malaysia's shari'ah courts (once again subject to state-level consent). She notes that 'JKSM has created Syariah Court laws for the Federal Territory of Kuala Lumpur, [but it] is expected that states in Malaysia will follow the Federal Territories Acts" (emphasis added). The Administration of Syariah Courts in Malaysia 1957-2009, Journal of IsLAmIC LAw AND Culture 13 (2011) at 250. See also Tamir Moustafa, Judging in God's Name: State Power, Secularism, and the Politics of Islamic Law in Malaysia, Oxford Journal of Law and Religion 3:1 (2014) at 152, 158, 161; Moustafa notes that Malaysia's state-level laws typically follow, and mirror, those enacted in the Federal Territories. 
the promulgation of no legislation instead. It may be that, via no legislation, the government has been able to advance two of its most enduring goals at once: on the one hand, mollifying the anxieties of Malaysia's regional sultans (jealous of their religious sovereignty); on the other, depriving the opposition (PAS) of an opportunity to criticize its legislation as "too soft".

Because the federal government, through JAKIM, has repeatedly stepped up its efforts to standardize state-level Islamic laws, particularly those on Muslim personal matters such as marriage, divorce, and inheritance, such political considerations are not inconceivable. ${ }^{120}$ Indeed, from an historical perspective, efforts to encourage centralization in matters pertaining to Islam can only be described as controversial, particularly in light of longstanding frictions regarding the balance between federal and state-level powers. Malaysia's sultans explicitly raised strong reservations during Malaysia's pre-independence constitution-making process about the inclusion of a provision cementing Islam as the religion of the Malayan federation (fearing that such a provision would shift the locus of authority in Islamic matters to the central government). It is only after these sultans received clear assurances that their regional authority in matters regarding Islam would not be lost that they agreed to the inclusion of this provision. In fact the sultans were assured that, even if a federal government department were established to address religious matters, that department would not exist under the purview of Malaysia's elected government - as it does (in the form of JAKIM) today. Instead, they were assured that such a department would only serve to "coordinate" the federation and the states under the purview of Malaysia's rotating king (i.e. the Yang di-Pertuan Agong). ${ }^{121}$ In other words, when it comes to Islam, the sultans associated with Malaysia's states are jealous of their state-level legislative power.

Since the earliest days of the constitution-making process, regional sultans have registered persistent concerns about the effect of non-Muslim proselytization amongst Muslims, with a particular focus on the "criminal" matter of Muslim apostasy. ${ }^{122}$ This is unsurprising insofar as Malaysia's sultans derive their authority from "[M]uslim notions of ... rule." ${ }^{123}$ Indeed, while the federal parliament may well pass laws to regulate the process of Muslim apostasy in Malaysia's Federal Territories, doing so would almost certainly stir up a host of constitutional and political questions regarding the shape of Malaysian federalism with respect to the terms of Islam, religious policy-making, and the religious prerogatives of Malaysia's hereditary sultans.

The statutory gap facing Lina Joy was awkward; but, for specific historical,

${ }^{120}$ Consider the experience with efforts to harmonize Islamic family law in the early 1980s. The federal parliament enacted its model law for the Federal Territories, which Penang, Perak, and Terengganu subsequently followed. Kelantan, however, enacted its own model law, which was preferred in Melaka. See Maria Luisa Seda-Poulin, Islamization and Legal Reform in Malaysia: The Hudud Controversy of 1992, Southeast Asian Affairs 224, 230 (1993).

${ }^{121}$ Shah, supra note 25 at 92.

${ }^{122} I d$. at 112 . It was for this reason that the sultans objected to the inclusion the right to propagate one's religion in the constitution.

${ }^{123}$ See M. B. Hooker, Muhammadan Law and Islamic Law, in Islam In South-East Asia 160, 171 (M. B. Hooker, ed.) and Donald L. Horowitz, Ethnic Groups in Conflict 226 (2000). 
constitutional, and political reasons, it is not difficult to understand why the behavior of the $\mathrm{NRD}$, drawing attention to state-level shari' $a$ h-court procedures and, therein, the need for a covering law promulgated by the relevant legislature, was considered legally "reasonable." Indeed, in this sense, even the acknowledgement of a glaring lacuna limiting the fundamental rights of Lina Joy was thought to serve, in some sense, a legitimate public interest-a legitimate interest in Malaysian federalism and its approach to the separation of powers (centre vs. state; executive vs. sultan; federal judiciary vs. state-level legislatures) as well as an interest in avoiding violent forms of religious criticism within the public at large.

To guarantee harmony between the versions of Islamic law that are applied in different units of the Malaysian federation, some have suggested that Malaysia should have a Grand Mufti "whose opinions would bind all Muslims." ${ }^{124}$ However, returning to Malaysia's constitutional and political arrangements, Farid Shuaib notes that this suggestion has not met with a positive response. "The federal government could not establish such an office", he explains, "unless the states voluntarily agree to subordinate their Muftis to a federal Mufti," and this is "something ... the states have resisted." statutory inaction that frustrated Lina Joy, Shuaib notes that the creation of a Grand Mufti able to make fatwas for the whole of Malaysia would require a constitutional amendment. But Malaysia's regional sultans "have shown their readiness to be firm in situation[s] related to their position." "Indeed, the constitutional amendment needed to specify a national punishment for the "crime" of Muslim apostasy was not introduced during the 50 years that UMNO and its BN coalition held the requisite two-thirds majority in parliament (1957-2008). With the demise of that super majority, the policy-making context pertaining to the regulation of Muslim apostasy and, therein, the operationalization of religious freedom has shifted; in short, the possibility of introducing a national "Grand Mufti" via the promulgation of a constitutional amendment has declined.

\section{CONCLUSION}

The right to freely choose one's religion (i.e. religious self-identification) and the formal procedures underpinning a state's recognition of one's faith are closely linked. They are tied together by administrative procedures, but the procedures considered "reasonable" vary from place to place in ways that directly shape the operationalization of religious freedom as a "right". In Malaysia, the operationalization of religious freedom is shaped by specific administrative procedures, but historical, constitutional, and political contingencies have shaped the way in which the procedures considered "reasonable" have been designed, including their absence in Malaysia's Federal Territories. These contingencies explain

${ }^{124}$ Shuaib (2012), supra note 28 at 111.

${ }^{125}$ Id. As Shuaib points out, "[t]here is a National Fatwa Committee, which was set up in 1970 and is currently placed within the Department of Islam of Malaysia in the Prime Minister's Office. This Committee may deliberate on issues relating to Islam but its recommendation ... is not binding on the states."

${ }^{126}$ Shuaib (2008), supra note 28 at 451. 
Malaysia's failure to close the procedural gap that prevented Lina Joy from transforming her religious "self-identification" into a case of "state recognition."

Conventionally, religious freedom is understood as a negative right, suggesting that states must not encroach on an individual's freedom to choose or change her religion. Precisely insofar as this right is guaranteed by state power, however, this formulation fails to appreciate the relationship between religious self-identification and the (historically contingent) administrative procedures underpinning state recognition. Indeed, the central issue in most cases is as follows: when do the administrative procedures underpinning state recognition amount to an "unreasonable" restriction on the manifestation of one's religious identity? At what point do administrative procedures become "unreasonable" in ways that constitute an abuse of human rights?

The case of Lina Joy reminds us that there is much to be gained (analytically) from a detailed empirical understanding of the relationship between religious self-identification and the historically and politically contingent questions of administrative "reasonableness" that underpin each state's recognition of religious identity (and, thus, its manifestation in the public realm). It is this empirical understanding of administrative "reasonableness" that, we argue, deserves more attention by those with an interest in the operationalization of religious freedom worldwide.

Registration requirements for religious identity are not uncommon. Aside from the Malaysian, American, and British cases of individual religious identity mentioned above, a study of 153 states with constitutional guarantees pertaining to freedom of worship shows that $42 \%$ impose some form of registration requirement with reference to religious groups. ${ }^{127}$ Indeed, even amongst those that constitutionalize a separation of religion and state, fully $86 \%$ enforce some form of religious-registration laws. ${ }^{128}$ Again, Lina Joy reminds us that religious freedom is protected so long as specific administrative procedures underpinning state-based recognition are satisfied. Asking Lina Joy to follow a set of procedures that did not yet exist may seem unreasonable; but, again, judgments of reasonableness are historically and politically contingent.

A Wednesbury test of administrative discretion seeks to identify cases in which state actors proceeding within a legislative grant of administrative discretion have, nevertheless, arrived at a decision that is "repugnant to all reason." "129 Moreover, such tests seek to highlight cases in which "some quality of perversity, arbitrariness, caprice, or absurdity" is present. ${ }^{130}$ The bar for unreasonableness is, thus, very high. In fact, as a political matter, tests of Wednesbury "unreasonableness" are widely understood to carve out a very broad "zone of immunity" protecting executive action from intrusive expressions of judicial review. ${ }^{131}$ This

${ }^{127}$ Jonathan Fox and Deborah Flores, Religions, Constitutions, and the State: A Cross-National Study, 41(4) J. Pol. 1499, 1509 (2009).

${ }^{128} \mathrm{Id}$. at 1510.

${ }^{129}$ Peiris, supra note 6 at 55.

${ }^{130} \mathrm{Id}$. at 56.

${ }^{131}$ Mark Elliot, The Human Rights Act 1998 and the Standard of Substantive Review, 60(2) CAMBRIDGE L. J. 301, 306 (2001). For criticism of the shift, within British jurisprudence, from a focus on (a) Wednesbury deference to administrative authority to (b) judge-led notions of proportionality, see Poole; Allan. 
pattern may have shifted in Europe and the U.K. But, as noted above, this is not the case in Malaysia.

In Malaysia, what many continue to see as an unreasonable administrative burden (or lacuna) was weighed against the constitutional and political implications associated with a Muslim exercising her religious freedom in a completely unfettered way, i.e. converting away from Islam without any prior approval from the relevant Islamic authorities. Given the negative sentiment broadly but not universally associated with Muslim apostasy in Malaysia (not to mention the media attention surrounding Lina Joy's case), Malaysia's Federal Court was clearly concerned that a decision in Joy's favor would create a political backlash from more conservative Muslims, not to mention a broader political clash involving Malaysia's regional sultans. There was also a concern that such a decision would jeopardize both the integrity and the security of Malaysia's Muslim community as a whole. This is clear in the Court's assertion that, had there been no limit on Muslim apostasy (that is, if Muslims were allowed to convert in and out of the religion as and when they wished), the community itself would fall into a state of "chaos."

In light of previous decisions like Md Hakim Lee, the lingering absence of explicit statutory provisions governing apostasy in the Federal Territories was not enough to persuade Malaysia's Federal Court that the NRD's conditions (requiring a certificate of apostasy from a shari'ah court) were "unreasonable". On the contrary, turning to questions of institutional competence, the Court held that it was entirely reasonable for the NRD to require such a certificate because apostasy was a matter to be addressed by religious experts according to Islamic principles. Requiring such a certificate, in other words, was within the ambit of the statutory discretion afforded to the NRD, and, more importantly, not so illogical (within the context of Malaysia's religious federalism) as to fall foul of a Wednesbury "unreasonableness" test. ${ }^{133}$ Indeed, the question of reasonableness in Lina Joy implicated a particularly sensitive feature of inter-branch politics: for historical, political, and constitutional reasons, the Federal Court simply refused to encroach on Malaysia's state-level shari'ah courts (and, by extension, Malaysia's state-level legislatures or sultans) in matters pertaining to Islam. More specifically, it was conscious not to disrupt the constitution's delicate approach to centre-state relations in matters pertaining to shari'ah. The Court believed that there was a clear constitutional mandate under the Ninth Schedule for Malaysia's state-level shari'ah courts to address such matters. Indeed, this exercise of judicial restraint in the face of complex political considerations and institutional competencies (underpinned by references to administrative "reasonableness") is not unusual in common-law jurisdictions worldwide.

In complex decisions framed by "political" constitutions that respect the notion of parliamentary primacy, the fact that political considerations underlie the operation of Wednesbury unreasonableness tests is well-established. And, yet, precisely insofar as this is the case, one wonders how a particular human right, constitutionally defined as a

\footnotetext{
${ }^{132}$ Lina Joy, supra note 3 at 612.

${ }^{133}$ For analogous considerations in Europe, see Jowell, supra note 73.
} 
"fundamental" right, can ever serve as a stable check on state power if, in due course, its operationalization is tied to politically contingent assessments of administrative "reasonable-ness" or, for that matter, a "proportional" appreciation for legitimate public interests? This is an important question that, we feel, deserves more attention in the literature on fundamental human rights. ${ }^{13}$

Malaysia's Federal Court concluded that the NRD had acted "reasonably" in the sense of arriving at a course of administrative action that made sense within the context of Malaysian history, Malaysian politics, and Malaysian constitutional law. In short, the Court concluded that the NRD's decision was not "so wrong that no reasonable person [in Malaysia] could sensibly be expected to reach it". Again, the meaning of reasonableness is always historically and politically contingent. But, precisely insofar as this is the case, we argue that the operationalization of religious freedom as a fundamental right, located in between religious self-identification and state recognition, is also (politically) contingent.

Can a defense of fundamental rights be ensured even after the administrative operationalization of those rights is foregrounded? Writing shortly after the promulgation of Britain's Human Rights Act in 1998, Mark Elliot argued that the standard of substantive review in English administrative law must now be viewed against a "constitutional backdrop" within which the Human Rights Act "forms a fundamental part." ${ }^{135}$ But, even before this Act came into force, Elliot explains that British courts had already begun to develop a doctrine of common law constitutional rights in which human rights cases were increasingly reviewed using the same proportionality analysis associated with the European Court of Human Rights. ${ }^{136}$ Even in administrative law cases, he explains, British courts had begun to embrace "a reconstructed version of the Wednesbury doctrine." ${ }^{137}$ Where British judges identified that a fundamental right had been restricted by an administrative procedure, they insisted on assessing the public-interest justification for that restriction. "Reasonableness" remained at the heart of such enquiries, ensuring that executive agents were still provided with a margin of administrative discretion. But, as Elliot explains, following T.R. Hickman, this "super-Wednesbury" approach provided for a far more rigorous review of administrative decisions - one that actively foregrounded the importance of fundamental human rights. ${ }^{139}$ Even a "reasonableness" assessment, in other words, need not preclude a serious consideration of rights. ${ }^{140}$

${ }^{134}$ With reference to the shift in British jurisprudence from Wednesbury 'reasonableness' tests to more thoroughgoing 'proportionality' tests after the European Court of Human Rights decision in Smith and Grady v. United Kingdom, see Rivers, supra note 6.

${ }^{135}$ Elliot, supra note 130 at 336.

${ }^{136}$ Id. at 326; see also Rivers supra note 6; Poole, supra note 4; and Jowell and Lester, supra note 6.

${ }^{137}$ Elliot, supra note 130 at 312.

${ }^{138}$ T. R. Hickman, The Reasonableness Principle: Reassessing Its Place in the Public Sphere, 63(1) CAmbridge L. J. 166, 185-6 (2004).

${ }^{139}$ Elliot, supra note 130 at 314. See also Hickman, id. at 186.

${ }^{140}$ In Casey (1992), the U.S. Supreme Court held that services (e.g. medical services) related to a constitutional right (a right to abortion) may be regulated. In this case, an "undue" or "unreasonable" burden could include "unnecessary health regulations that have the purpose or effect of presenting a substantial obstacle 
In the future, we may see a similar shift enabling fundamental rights to serve as a more effective check on executive power in Malaysia. We simply argue that any effort to grasp such a transition will require an appreciation for the political dynamics underpinning Malaysia's constitutional experience.

to a woman seeking an abortion." Whereas the U.S. Supreme Court has increasingly intervened to regulate state-level administrative procedures (e.g. official forms) pertaining to state and federal rights like marriage or religious freedom, the Malaysian Federal Court has, for historical and political reasons of its own, shied away from any similar assertion of federal supremacy, exercising considerably more restraint. This is closer to the U.S. Supreme Court's Erie doctrine, which tries to discourage forum-shopping where the jurisdictions of federal and state-level courts overlap by encouraging federal judges to decide cases in ways that mirror the laws of the state in question. See Redding, supra note 9. 